\title{
Discrimination factors of carbon and nitrogen stable isotopes in meerkat feces
}

\author{
Shaena Montanari ${ }^{\text {Corresp. } 1}$ \\ ${ }^{1}$ School of GeoSciences, University of Edinburgh, Edinburgh, United Kingdom \\ Corresponding Author: Shaena Montanari \\ Email address: shae.montanari@gmail.com
}

Stable isotope analysis of feces can provide a non-invasive method for tracking the dietary habits of nearly any mammalian species. While fecal samples are often collected for macroscopic and genetic study, stable isotope analysis can also be applied to expand the knowledge of species-specific dietary ecology. It is somewhat unclear how digestion changes the isotope ratios of animals' diets, so more controlled diet studies are needed. To date, most diet-to-feces controlled stable isotope experiments have been performed on herbivores, so in this study I analyzed the carbon and nitrogen stable isotope ratios in the diet and feces of the meerkat (Suricata suricatta), a small omnivorous mammal. The carbon trophic discrimination factor between diet and feces $\left(\Delta^{13} \mathrm{C}_{\text {feces }}\right)$ is calculated to be $0.1 \pm 1.5 \%$, which is not significantly different from zero, and in turn, not different than the dietary input. On the other hand, the nitrogen trophic discrimination factor $\left(\Delta^{15} \mathrm{~N}_{\text {feces }}\right)$ is $1.5 \pm 1.1 \%$, which is significantly different from zero, meaning it is different the average dietary input. Based on data generated in this experiment and a review of the published literature, carbon isotopes of feces characterize diet, while nitrogen isotope ratios of feces are consistently higher than dietary inputs, meaning a discrimination factor needs to be taken into account. The carbon and nitrogen stable isotope values of feces are an excellent snapshot of diet that can be used in concert with other analytical methods to better understand ecology, diets, and habitat use of mammals. 
1

2 Discrimination Factors Of Carbon And Nitrogen Stable Isotopes In Meerkat Feces

3

4 Shaena Montanari

5 School of GeoSciences, University of Edinburgh, Grant Institute, Edinburgh, UK EH9 3FE

6

$7 \quad$ Email: Shae.montanari@gmail.com

8

9

10

11

12

13

14

15

16

17

18

19

20

21

22

23

24 


\section{Abstract}

26 Stable isotope analysis of feces can provide a non-invasive method for tracking the dietary habits

27 of nearly any mammalian species. While fecal samples are often collected for macroscopic and

28 genetic study, stable isotope analysis can also be applied to expand the knowledge of species-

29 specific dietary ecology. It is somewhat unclear how digestion changes the isotope ratios of

30 animals' diets, so more controlled diet studies are needed. To date, most diet-to-feces controlled

31 stable isotope experiments have been performed on herbivores, so in this study I analyzed the

32 carbon and nitrogen stable isotope ratios in the diet and feces of the meerkat (Suricata suricatta),

33 a small omnivorous mammal. The carbon trophic discrimination factor between diet and feces

$34\left(\Delta^{13} C_{\text {feces }}\right)$ is calculated to be $0.1 \pm 1.5 \%$, which is not significantly different from zero, and in

35 turn, not different than the dietary input. On the other hand, the nitrogen trophic discrimination

36 factor $\left(\Delta^{15} \mathrm{~N}_{\text {feces }}\right)$ is $1.5 \pm 1.1 \%$, which is significantly different from zero, meaning it is different

37 the average dietary input. Based on data generated in this experiment and a review of the

38 published literature, carbon isotopes of feces characterize diet, while nitrogen isotope ratios of

39 feces are consistently higher than dietary inputs, meaning a discrimination factor needs to be

40 taken into account. The carbon and nitrogen stable isotope values of feces are an excellent

41 snapshot of diet that can be used in concert with other analytical methods to better understand

42 ecology, diets, and habitat use of mammals.

\section{Introduction}

45 Small mammals are an important and often overlooked in favor of larger more charismatic

46 species, but they fill vital roles as ecosystem engineers, prey base, and seed dispersal agents

47 (Huntly \& Inouye, 1988; Brown \& Heske, 1990; Davidson, Detling \& Brown, 2012;). They 
48

49

50

51

52

53

54

55

56

57

58

59

60

61

62

63

66

67

68

69

70

often live in colonies or in large numbers; therefore their plentiful modern and historical remains can provide records of changing environments and shifting ecological conditions (Terry, 2010). Non-invasive monitoring is an ideal way to track changes in modern mammalian communities, as shed hair and feces can provide a substrate for examining population trends, diets, and health of groups using genetic or chemical methods (Crawford, McDonald \& Bearhop, 2008, Pompanon et al., 2012; Rodgers \& Janecka, 2012;). Specifically examining feces is useful, as it can be collected from rare or cryptic species that are hard to monitor and often avoid humans. Also, feces is plentiful and relatively inexpensive to analyze. Traditionally, vertebrate diets have been assessed macroscopically through physical examination of gut contents and feces (e.g. Hermsen, Kerle, \& Old 2016). With the advent of affordable high-throughput sequencing, fecal studies are becoming more common for barcoding dietary DNA, which allows for a more complete dietary picture not as easily biased by differing digestibility of food (e.g. Shehzad et al., 2012; Kartzinel et al., 2015). Stable isotope methods can provide a useful complement to these barcoding studies that are growing in popularity. Fecal stable isotopes have been useful for detecting dietary shifts in mammals such as gorillas (Blumenthal et al., 2012), for understanding weaning time in primates (Reitsema, 2015), and as a climate record from bats (Royer et al., 2015), so understanding isotopic discrimination and variability of this material is vital for future research.

7 Stable isotope ratios of nitrogen $\left({ }^{15} \mathrm{~N} /{ }^{14} \mathrm{~N}\right.$, written $\left.\delta^{15} \mathrm{~N}\right)$ and carbon $\left({ }^{13} \mathrm{C} /{ }^{12} \mathrm{C}\right.$, written $\left.\delta^{13} \mathrm{C}\right)$ are incorporated in animal tissues and excretions following digestion of food products. Changes in stable isotope ratios can elucidate information about food webs, trophic structure, and habitat use (Ben-David \& Flaherty, 2012). It is assumed that carbon isotope ratios do not fractionate 
71 drastically as they propagate through the food web (DeNiro \& Epstein, 1978), and in terrestrial

72 ecosystems, these ratios are generally used to indicate the primary production at the base of the

73 food web. Carbon isotope ratios of plants that use different metabolic pathways (C3, C4, or

74 CAM) are systematically different, and this difference is incorporated into the tissues or

75 byproducts of consumers. On the other hand, $\delta^{15} \mathrm{~N}$ values are known to become enriched as

76 trophic level increases (DeNiro \& Epstein, 1981), and differences in $\delta^{15} \mathrm{~N}$ of tissue over time or

77 between populations can be used to discern changes in food webs, habitat, or prey composition

78 (Post, 2002).

79

To use stable isotopes in dietary ecology, there has to be a comprehensive understanding of the difference in isotope ratios between diet and tissue (or feces); this difference is called the trophic discrimination factor (also fractionation factor or discrimination factor) and arises due to causes like isotopic fractionation during digestion and metabolism. Trophic discrimination factor is denoted as $\Delta$ and defined as $\Delta=\delta_{\text {tissue }}-\delta_{\text {diet }}$ (Martínez del Rio et al., 2009). Trophic discrimination factors (abbreviated TDFs) are widely variable among animals and differ depending on species, tissue examined, and diet type and quality (Caut, Angulo \& Courchamp, 2009). General TDFs are used in many mixing model studies for animal diet reconstruction, but it has been shown that small differences in TDFs in these types of studies can lead to vastly different conclusions about dietary makeup (Ben-David \& Schell, 2001). Experimental work by Caut, Angulo \& Courchamp 90 (2008) shows that mixing models are most accurate when species-specific TDFs are obtained.

92 In this study, I calculate TDFs for carbon and nitrogen isotopes in meerkat (Suricata suricatta)

93 feces in order to obtain fecal TDFs in a small mammalian omnivore. Meerkats are small, diurnal 
94 mammals that are members of Carnivora and are herpestids, closely related to mongoose. They

95 have generalist diets and in the wild consume insects, berries, reptiles, and other small

96 invertebrates (Doolan \& Macdonald, 1996). The diets of generalist consumers are difficult to

97 study in the wild due to unknown variability in their diet, so a zoo-based study of meerkats in

98 this instance will provide dietary control, allowing for less unknown variation in the

99 determination of TDF. Studies like this one are necessary, as TDFs are not often determined for

100 terrestrial mammalian omnivores and carnivores or even feces in general (Table 1. \& Table 2.).

101 Even though feces represent a snapshot of diet, it is often collected in sizeable quantities for non-

102 invasive studies. This can provide important ecological and environmental records and elucidate

103 short-term and seasonal dietary variability. Changes in isotope ratios from diet to feces need to

104 be calculated, as there may be isotopic fractionation from the process of digestion and waste 105 excretion.

106

107 Here I calculate trophic discrimination factors for captive meerkats by measuring the isotopic 108 composition of both the diet and the feces. I also describe how fecal stable isotope values vary

109 over short periods of time so that more information can be gleaned about the measured

110 variability in generalist diets during wild studies. Focusing on small mammals with generalist

111 diets will be key to uncovering ecological factors that cause shifts in mammalian biodiversity, as 112 small mammals are accurate recorders of environmental change over a variety of time scales

113 (Barnosky et al., 2003; Terry, 2010).

114

115 Materials and Methods

116 Diet and feces samples 
117 The meerkats in this study are maintained at the Edinburgh Zoo (Royal Zoological Society

118 Scotland). Fecal samples were taken randomly from an enclosure containing 7 adult female

119 meerkats over the course of April 2016. Subsamples of diet were collected once a week for four

120 weeks to account for variability in diet items. Per the information of Edinburgh Zoo animal care

121 workers, the meerkats are fed different combinations of the food items each day, but over the

122 course of a week the amount of each item they eat is roughly equal. Each animal receives the

123 same amount of each food item by weight. A total of 24 fecal samples were collected, along with

124 2-4 subsamples of each diet item: carrots and apples, horsemeat, dog biscuits, whole frozen small

125 mice, and whole frozen chicks. The above items were used to calculate the trophic discrimination

126 factor from diet to feces. Homogenized bulk muscle with attached skin was sectioned from the

127 whole chicks and mice for analysis.

128

\section{Stable isotope analysis}

130 Stable isotope analysis was conducted at the Wolfson Laboratory in the School of Geosciences at

131 the University of Edinburgh. The analysis of carbon and nitrogen isotope ratios was performed

132 on a CE Instruments NA2500 Elemental Analyzer and the effluent gas was analyzed for its

133 carbon and nitrogen isotopic ratios using a Thermo Electron Delta+ Advantage stable isotope

134 ratio mass spectrometer. Sediment standard, PACS-2 $\left(\delta^{15} \mathrm{~N} 5.215 \%\right.$ (Air) and $\delta^{13} \mathrm{C}-22.228 \%$ o

135 (VPDB)) from the National Research Council Canada was used for isotopic analyses.

136 Acetanilide standard (C 71.09\% and N 10.36\%) was used for elemental compositions. Isotopic

137 data were determined relative to $\mathrm{CO}_{2}$ and $\mathrm{N}_{2}$ reference gases whose mean values are derived

138 from the average value of PACS-2 samples within each daily run.

139 
140 The standard deviation for 5 analyses of the PACS-2 standard run over the same time period as

141 the study samples was $\pm 0.07 \%$ for $\delta^{13} \mathrm{C}$ (VPDB), and $\pm 0.14 \%$ for $\delta^{15} \mathrm{~N}$ (Air). Elemental

142 analysis, measuring the percentage of carbon and nitrogen in the samples, had an error of $1 \%$ for

143 carbon and $4 \%$ for nitrogen. The stable isotope ratios are reported in standard notation and

144 referenced to air for $\delta^{15} \mathrm{~N}$ values and Vienna Pee Dee Belemnite (VPDB) for $\delta^{13} \mathrm{C}$ values. Ratios

145 are defined as $\delta=\left(\mathrm{R}_{\text {sample }} / \mathrm{R}_{\text {standard }}-1\right)$ where $\mathrm{R}={ }^{13} \mathrm{C} /{ }^{12} \mathrm{C}$ or ${ }^{15} \mathrm{~N} /{ }^{14} \mathrm{~N}$.

146

147 Samples were prepared first by lyophilization followed by manual crushing to form a

148 homogenized powder for isotope analysis. Feces and diet samples were subsampled and

149 analyzed both with and without lipid extraction treatment. The samples were lipid extracted by

150 immersion in a 2:1 ratio of chloroform/methanol for 12 hours using a Soxhlet apparatus.

151 Following lipid extraction, samples were dried in a $50^{\circ} \mathrm{C}$ oven for at least 24 hours to evaporate 152 any remaining solvent.

153

\section{Statistics and Data Analysis}

155 Statistical tests and analyses were performed in R (R Core Team, 2016), and plots were created 156 in ggplot2 (Wickham, 2009). Trophic discrimination factors were calculated using the averages 157 of all subsampled dietary material. TDFs were calculated for both $\delta^{13} \mathrm{C}$ and $\delta^{15} \mathrm{~N}$ using the 158 aforementioned equation $\Delta \mathrm{X}_{\text {feces }}=\delta \mathrm{X}_{\text {feces }}-\delta \mathrm{X}_{\text {diet }}$ where $\Delta \mathrm{X}_{\text {feces }}$ is calculated in per mil (\%o). $\delta \mathrm{X}_{\text {diet }}$

159 is the value of the average of all non-lipid-extracted dietary samples and $\delta X_{\text {feces }}$ is each individual 160 fecal stable isotope value. 
162 Parametric statistical tests were performed, as the data are normally distributed as shown through

163 a Shapiro-Wilk test $\left(\delta^{13} \mathrm{C}: \mathrm{W}=0.946, \mathrm{p}=0.057 ; \delta^{15} \mathrm{~N}: \mathrm{W}=0.976, \mathrm{p}=0.544\right)$. Before hypothesis

164 testing, an F-test was performed to see if a t-test for equal or unequal variance (Welch two

165 sample t-test) should be done based on the results. F-tests show the variance was equal for

166 comparisons between lipid-extracted and non-lipid-extracted feces for both $\delta^{13} \mathrm{C}$ and $\delta^{15} \mathrm{~N}\left(\delta^{13} \mathrm{C}\right.$ :

$\left.167 \mathrm{~F}_{8,23}=1.409, \mathrm{p}=0.491 ; \delta^{15} \mathrm{~N}: \mathrm{F}_{8,23}=0.408, \mathrm{p}=0.191\right)$. Variance for comparisons between diet

168 and feces for both $\delta^{13} \mathrm{C}$ and $\delta^{15} \mathrm{~N}$ are unequal $\left(\delta^{13} \mathrm{C}: \mathrm{F}_{15,23}=5.001, \mathrm{p}=0.0006 ; \delta^{15} \mathrm{~N}: \mathrm{F}_{15,23}=\right.$

$1692.633, \mathrm{p}=0.036)$. All means are reported \pm standard deviation (SD), and all significance is

170 reported for $\alpha=0.05$.

171

172 To obtain carbon and nitrogen fecal trophic discrimination factors from other studies for

173 comparison to results from this study, a literature search was conducted using Google Scholar

174 and through mining references in other feces trophic discrimination factor papers. These were all

175 of the papers with diet-feces trophic discrimination factors found as of August 2016 searching

176 keywords such as "feces stable isotopes" and "scat stable isotopes". These values appear in

177 Table 1 and Table 2.

178

179 Results

180 A summary of the stable isotope results is presented in Table 3, and a summary of t-tests is

181 reported in Table 4. All raw isotope data can be found in the supplementary information (Data

182 S1.).

183 
184 A subset of feces and diet samples were lipid extracted to see if this changed the results of the

185 analysis; however, using a t-test no significant difference was found between the $\delta^{13} \mathrm{C}$ and $\delta^{15} \mathrm{~N}$

186 of either material between lipid extracted and non-lipid-extracted samples (Table 4.). As in my

187 previous study of fecal TDFs (Montanari \& Amato, 2015), I have opted to use only non-lipid-

188 extracted materials for sampling, as a meta-analysis of carbon and nitrogen discrimination

189 factors from Caut et al., (2009) has shown that lipid extraction has no significant effect on 190 calculated TDFs.

191

192 The mean $\delta^{13} \mathrm{C}$ value for each food item is as follows: chick ( $\mathrm{n}=2,-26.1 \pm 1.2 \%$ ), mouse $(\mathrm{n}=2$, -

$19323.4 \pm 1.7 \%$ ), horsemeat $(n=4,-27.1 \pm 1.3 \%$ ), carrots and apple mix $(n=4,-27.7 \pm 1.5 \% 0)$, and dog

194 biscuits $\left(n=4,-20.2 \pm 0.5 \%\right.$ ). The average for all diet items $(n=16)$ is $-24.9 \pm 3.3 \%$. Mean $\delta^{15} \mathrm{~N}$

195 values are: chick $(4.5 \pm 0.03 \%$ ), mouse $(5.2 \pm 0.6 \%)$, horsemeat $(7.0 \pm 1.3 \%$ ), carrots and apple mix

$196\left(3.5 \pm 1.0 \%\right.$ ) , and dog biscuits $\left(2.9 \pm 0.5 \%\right.$ ). The average $\delta^{15} \mathrm{~N}$ for all diet items is $4.6 \pm 1.8 \%$. The

197 mean diet $\mathrm{C} / \mathrm{N}$ ratio is $27.1 \pm 38.1$. The mean $\delta^{13} \mathrm{C}$ value of the feces is $-24.8 \pm 1.5 \%$ and the mean

$198 \delta^{15} \mathrm{~N}$ value is $6.1 \pm 1.1 \%$. The $\mathrm{C} / \mathrm{N}$ ratio is $6.9 \pm 1.6$. The ranges and variability of $\delta^{13} \mathrm{C}$ and $\delta^{15} \mathrm{~N}$

199 for all materials are presented in Table 3 and the variation of fecal isotope values over the month

200 they were collected is presented in Fig. 1. When the fecal samples were placed into bins by

201 weeks they were collected and subjected to an ANOVA, there was no difference between the

202 average weekly scat values over the course of the month $\left(\delta^{13} \mathrm{C}: \mathrm{F}_{4,19}=0.539, \mathrm{p}=0.709 ; \delta^{15} \mathrm{~N}\right.$ :

$\left.203 \mathrm{~F}_{4,19}=0.886, \mathrm{p}=0.491\right)$.

204

205 The $\delta^{13} \mathrm{C}$ and $\delta^{15} \mathrm{~N}$ values of feces and diet were compared to establish if there is a significant 206 difference between them. In the case of $\delta^{13} \mathrm{C}$ there is no significant difference (Welch two- 
207 sample $\mathrm{t}$-test $, \mathrm{t}=-0.14, \mathrm{df}=19.05, \mathrm{p}=0.89)$ while for $\delta^{15} \mathrm{~N}$ the means are significantly different

208 (Welch two sample t-test, $\mathrm{t}=-2.97, \mathrm{df}=22.61, \mathrm{p}=0.01$ ). Discrimination factors were calculated by

209 using the average value of all diet items subtracted from each individual feces sample in order to 210 assess variance. Average $\Delta^{13} \mathrm{C}$ for feces $\left(\Delta^{13} \mathrm{C}_{\text {feces }}\right)$ is $0.1 \pm 1.5 \%$ and $\Delta^{15} \mathrm{~N}$ for feces $\left(\Delta^{15} \mathrm{~N}_{\text {feces }}\right)$ is $2111.5 \pm 1.1 \%$, with only the $\Delta^{15} \mathrm{~N}_{\text {feces }}$ being significantly different than zero.

212

213 Discussion

\section{Trophic discrimination factors of meerkat feces}

215 Feces can be an extremely useful substrate for stable isotope analysis for estimating food input, 216 and these data show in meerkats that in relation to carbon isotopes, feces are a fair representation 217 of diet, but nitrogen isotopes of feces on the other hand undergo isotopic enrichment.

218 Investigations into stable isotope discrimination factors show that herbivore feces are

219 representative of diet in large bodied animals (Sponheimer et al., 2003a) but that in small-bodied 220 herbivores (Hwang et al., 2007) and non-herbivores (Montanari \& Amato 2015) feces undergo

221 enrichment of nitrogen isotopes within the digestive tract. In this study, the trophic

222 discrimination factor of carbon isotopes from diet-to-feces is small and not statistically

223 significant. Similar results for $\Delta^{13} \mathrm{C}_{\text {feces }}$ are seen in studies of insectivores (bats, Salvarina et al., 224 2013) and carnivores (tigers and snow leopards, Montanari \& Amato, 2015). To this point, 225 experimental research on diet-to-feces discrimination factors shows most calculated carbon 226 TDFs are non-significant as referenced by the review of published studies in Table 1. More data 227 are needed on more mammalian omnivores and carnivores to further assess this pattern. 
229 The means of $\delta^{15} \mathrm{~N}_{\text {diet }}$ and $\delta^{15} \mathrm{~N}_{\text {feces }}$ are different (Table 4.); therefore the $\Delta^{15} \mathrm{~N}_{\text {feces }}$ value

$230(1.5 \pm 1.1 \%$ o $)$ is significantly different than zero. In this study and the other two non-herbivore

231 fecal TDF studies of Salvarina et al. (2013) and Montanari and Amato (2015), $\Delta^{15} \mathrm{~N}_{\text {feces }}$ is of

232 similar magnitude and also the only TDF that is different than zero; although $\Delta^{15} \mathrm{~N}_{\text {feces }}$ is only

233 significant in one out of two species examined in each of these studies. Nevertheless,

234 significance of $\Delta^{15} \mathrm{~N}_{\text {feces }}$ could indicate ${ }^{15} \mathrm{~N}$ enrichment occurs during digestion, likely during

235 transit through the gut as is seen in Hwang, Millar, \& Longstaffe (2007). This study investigated

$236 \delta^{15} \mathrm{~N}$ values at different parts in the digestive tract of voles and other small rodents and found

237 digested material is enriched in ${ }^{15} \mathrm{~N}$ in the stomach, intestine, cecum, and colon relative to the

238 diet. It has also been shown the $\delta^{15} \mathrm{~N}$ of mucosal epithelium was higher than the diet input in

239 some parts of the digestive tract of a sheep, which suggests the enrichment in ${ }^{15} \mathrm{~N}$ in feces may

240 be due to the presence of endogenous proteins (Sutoh et al., 1993). In general, significant $\Delta^{15} \mathrm{~N}$

241 values point to some relationship between digestive processes and $\Delta^{15} \mathrm{~N}$, but the cause is

242 unknown and more experiments comparing ${ }^{15} \mathrm{~N}$ enrichment during digestion in herbivores and

243 non-herbivores are needed.

244

245 A number of other factors may be also affecting nitrogen flux during digestion and excretion.

246 Different biochemical pathways related to the changes in proteins occurring during digestion

247 (deamination/amination) could be the cause of ${ }^{15} \mathrm{~N}$ enrichment (Hwang et al., 2007).

248 Additionally, the presence of microorganisms in the digestive tract could also be making the

249 fecal matter enriched when compared to diet (Hwang et al., 2007, Macko et al., 1987). The ${ }^{15} \mathrm{~N}$

250 enrichment could be due to preferential absorption of ${ }^{14} \mathrm{~N}$ by the animal during digestion or

251 removal during urine excretion, but experimental data from Sponheimer et al. (2003b) seem to 
252 indicate that at least in herbivores, ${ }^{14} \mathrm{~N}$ is not preferentially excreted. In Montanari and Amato

253 (2015), we cautioned that more data should be collected to better understand TDFs of carnivores

254 because the physiological mechanisms are still unknown; this study continues in the same vein

255 and reinforces that there is a preferential loss of ${ }^{14} \mathrm{~N}$ and/or enrichment in ${ }^{15} \mathrm{~N}$ occurring during

256 movement through the gastrointestinal tract in relation to solid waste. Further mammalian

257 physiological experiments may explain the mechanism.

258

\section{Variables that affect trophic discrimination factors}

260 It has been shown that TDFs vary due to a number of factors, one of them being the initial

261 isotopic ratio of the diet. Significant relationships between both $\delta^{13} \mathrm{C}$ and $\delta^{15} \mathrm{~N}$ of diets and TDFs

262 have been shown in bears (Hilderbrand et al., 1996; Felicetti et al., 2003), rats (Caut et al., 2008),

263 and birds (Pearson et al., 2003). A meta-analysis of TDFs and dietary isotope ratios values by

264 Caut et al. (2009) finds significant negative relationships between these variables in both carbon

265 and nitrogen. A similar study of this relationship with fecal TDFs can be completed due to the

266 fact most of the calculated fecal TDFs are not significantly different from 0 (data from Table 1.

$267 \&$ Table 2.). This could be due to the fact that feces represents immediately ingested diet (within

268 hours or days) as opposed to assimilated diet and is not subjected to as many physiological

269 processes of fractionation. This is a promising result for the use of feces in isotope studies

270 because the variability of TDFs due to dietary input is a major issue for stable isotope food web

271 studies. Variability that needs to be accounted for with other tissues (Caut et al., 2009) appears to

272 be a non-issue in feces.

273 
274 Mammalian body size might influence calculated TDF (Hwang et al., 2007). A mechanism that

275 could explain this is a general trend of higher mass-specific metabolism in animals with smaller

276 body mass (Kleiber's law), which could in turn impact the fractionation of isotopes that occurs

277 after food ingestion (Pecquerie et al., 2010). Hwang et al. (2007) did a meta-analysis of fecal

278 TDFs in the literature combined with their rodent TDFs and found significant differences in $\Delta^{13} \mathrm{C}$

279 between different body sizes, but only in herbivores. A lack of published fecal TDFs for non-

280 herbivorous mammals of different sizes means statistical test cannot be performed for herbivores

281 vs. non-herbivores.

282

\section{Isotopic variability over time}

284 Not only can feces be used for point estimates of diet, but also long term collection is especially

285 useful for finding seasonal patterns in dietary variability (e.g., Blumenthal et al., 2012).

286 Mammalian carnivores and omnivores tend to change their diets seasonally, so it is important to

287 realize the magnitude of fecal isotope variation day-to-day for wild studies (e.g. Kincaid \&

288 Cameron 1982; Melero et al. 2008). Other than this study, Blumenthal et al. (2012) and Salvarina

289 et al. (2013) track stable isotope ratios of animal feces at monthly or daily intervals respectively.

290 I have tracked meerkat fecal stable isotopes over the course of one month, and it is clear there is

291 variation on any given day a sample is taken (Fig. 1), as the combination of diet items they eat

292 changes daily. There is a range of $7.3 \%$ in the $\delta^{13} \mathrm{C}$ and $4.5 \%$ o $\delta^{15} \mathrm{~N}_{\text {feces }}$ of meerkat feces over a

293 month. This suggests feces can be directly reflective of a highly variable diet, and also shows

$294 \delta^{13} C_{\text {feces }}$ may not be buffered in small mammals as much against day-to-day variability as in

295 larger mammals (Blumenthal et al., 2012). It is not known exactly how long it takes isotopes of

296 feces to reach dietary equilibrium in meerkats, but in Salvarina et al. (2013) it was shown that bat 
297 feces acquired a new dietary signal in 2-3 hours so it stands to reason it is also within hours for a

298 small mammal. Examining the daily fluctuations in $\delta^{13} \mathrm{C}$ and $\delta^{15} \mathrm{~N}$ in feces indicates timing of

299 major dietary changes can be pinpointed quite precisely using this method, at least within days.

300 Due to the fact the TDFs in this study were calculated using an average diet value, the TDF is

301 also averaged and is meant to act as a general guide for a TDF in the wild. This variability is

302 important to realize for wild studies, as it emphasizes the need for larger sample sizes of feces,

303 such as multiple samples per day or week, to lessen the impact of day-to-day variability if

304 researchers are seeking a long-term ecological or environmental trend (e.g. Blumenthal et al., 305 2012).

306

\section{Conclusions}

308 I found the $\delta^{13} C_{\text {feces }}$ of captive meerkats was not changed compared to the dietary input, while

$309 \delta^{15} \mathrm{~N}_{\text {feces }}$ is higher than diet. Compared with other published fecal TDFs, the meerkat data fit with 310 observed trophic discrimination factors, and also show that an enrichment of ${ }^{15} \mathrm{~N}$ and/or a

311 depletion of ${ }^{14} \mathrm{~N}$ is occurring during digestion or in the gut during gastrointestinal transit. When 312 these TDFs are compared to other fecal TDFs in published literature, they are similar in that they 313 are mostly non-significant, which removes one layer of uncertainty when using feces in wild 314 animal studies. Looking at the stable isotope ratios for both carbon and nitrogen over the course 315 of the month, it is clear short-term, near-daily variability in diet can be captured using stable 316 isotope analysis of meerkat feces. Captive studies like this one with more controlled feces and 317 diet collection parameters will hopefully lead to better understanding in other understudied 318 groups, like terrestrial small and medium sized mammals with omnivorous diets, so that stable 319 isotope analysis of feces can become a more common tool in mammalian stable isotope ecology. 


\section{Acknowledgements}

322 The author thanks the animal care staff at Edinburgh Zoo for collecting the diet and feces

323 samples and facilitating this research project. Thanks are extended to Colin Chilcott and Steve

324 Mowbray at the University of Edinburgh for help preparing and analyzing all samples stable

325 isotope analysis. The author gives many thanks for reviews and comments from Roberto

326 Ambrosini and two other anonymous reviewers that greatly improved this manuscript.

327

328 References

329 Barnosky AD, Hadly EA, Bell CJ. 2003. Mammalian response to global warming on varied

330 temporal scales. Journal of Mammalogy 84, 354-368. DOI:10.1644/1545-

331 1542(2003)084<0354:MRTGWO>2.0.CO;2

332

333 Ben-David M, Flaherty EA. 2012. Stable isotopes in mammalian research: a beginner's guide.

334 Journal of Mammalogy 93: 312-328. DOI: 10.1644/11-MAMM-S-166.1

335

336 Ben-David M, Schell DM. 2001. Mixing models in analyses of diet using multiple stable

337 isotopes: a response. Oecologia 127: 180-184. DOI: 10.1007/s004420000570

338

339 Blumenthal SA, Chritz KL, Rothman JM, Cerling TE. 2012. Detecting intraannual dietary

340 variability in wild mountain gorillas by stable isotope analysis of feces. Proceedings of the

341 National Academy of Sciences 109: 21277-21282. DOI: 10.1073/pnas.1215782109. 
343 Brown JH, Heske EJ. 1990. Control of a desert-grassland transition by a keystone rodent guild.

344 Science 250: 1705-1707. DOI: 10.1126/science.250.4988.1705.

345

346 Caut S, Angulo E, Courchamp F. 2008. Discrimination factors $\left(\Delta^{15} \mathrm{~N}\right.$ and $\left.\Delta^{13} \mathrm{C}\right)$ in an

347 omnivorous consumer: effect of diet isotopic ratio. Functional Ecology 22: 255-263. DOI:

348 10.1111/j.1365-2435.2007.01360.x.

349

350 Caut S, Angulo E, Courchamp F. 2009. Variation in discrimination factors $\left(\Delta^{15} \mathrm{~N}\right.$ and $\left.\Delta^{13} \mathrm{C}\right)$ : the 351 effect of diet isotopic values and applications for diet reconstruction. Journal of Applied Ecology 352 46: 443-453. DOI: 10.1111/j.1365-2664.2009.01620.x.

353

354 Crawford K, McDonald RA, Bearhop S. 2008. Applications of stable isotope techniques to the 355 ecology of mammals. Mammal Review 38: 87-107. DOI: 10.1111/j.1365-2907.2008.00120.x.

356

357 Davidson AD, Detling JK, Brown JH. 2012. Ecological roles and conservation challenges of 358 social, burrowing, herbivorous mammals in the world's grasslands. Frontiers in Ecology and the 359 Environment 10: 477-486. DOI: 10.1890/110054.

360

361

DeNiro MJ, Epstein S. 1978. Influence of diet on the distribution of carbon isotopes in animals.

362 Geochimica et Cosmochimica Acta 42: 495-506. DOI:10.1016/0016-7037(78)90199-0.

363

364 DeNiro MJ, Epstein S. 1981. Influence of diet on the distribution of nitrogen isotopes in animals.

365 Geochimica et Cosmochimica Acta 45: 341-351. DOI:10.1016/0016-7037(81)90244-1. 
367 Doolan SP \& Macdonald DW. 1996. Diet and foraging behaviour of group-living meerkats,

368 Suricata suricatta, in the southern Kalahari. Journal of Zoology 239: 697-716.

369 DOI:10.1111/j.1469-7998.1996.tb05472.x.

370

371 Felicetti LA, Schwartz CC, Rye RO, Haroldson MA, Gunther KA, Phillips DL, Robbins CT. 372 2003. Use of sulfur and nitrogen stable isotopes to determine the importance of whitebark pine 373 nuts to Yellowstone grizzly bears. Canadian Journal of Zoology 81: 763-770. DOI: 10.1139/z03374054

375

376 Hermsen E, Kerle A, Old, JM. 2016. Diet of an inland population of the common ringtail possum 377 (Pseudocheirus peregrinus). Australian Mammalogy 38:130-134. DOI: 10.1071/AM15008.

379 Hilderbrand GV, Farley SD, Robbins CT, Hanley TA, Titus K, Servheen C. 1996. Use of stable 380 isotopes to determine diets of living and extinct bears. Canadian Journal of Zoology 74: 2080381 2088. DOI: 10.1139/z96-236.

382

383 Huntly N, Inouye R. 1988. Pocket gophers in ecosystems: patterns and mechanisms. BioScience 384 38: 786-793. DOI: $10.2307 / 1310788$.

385

386 Hwang T, Millar S, Longstaffe J. 2007. Do $\delta 15 \mathrm{~N}$ and $\delta 13 \mathrm{C}$ values of feces reflect the isotopic 387 composition of diets in small mammals? Canadian Journal of Zoology 85: 388-396. DOI: 388 10.1139/Z07-019. 
390 Kartzinel TR, Chen PA, Coverdale TC, Erickson DL, Kress WJ, Kuzmina ML, Rubenstein

391 DI, Wang W, Pringle RM. 2015. DNA metabarcoding illuminates dietary niche partitioning by

392 African large herbivores. Proceedings of the National Academy of Science 112: 8019-8024.

393 DOI:10.1073/pnas.1503283112

394

395 Kincaid WB, Cameron GN. 1982. Dietary variation in three sympatric rodents on the Texas 396 Coastal Prairie. Journal of Mammalogy 63: 668-672. DOI: 10.2307/1380277.

397

398 Macko SA, Fogel ML, Hare PE, Hoering TC. 1987. Isotopic fractionation of nitrogen and carbon

399 in the synthesis of amino acids by microorganisms. Chemical Geology: Isotope Geoscience 65:

400 79-92. DOI:10.1016/0168-9622(87)90064-9

401

402 Martínez del Rio C, Wolf N, Carleton SA, Gannes LZ. 2009. Isotopic ecology ten years after a 403 call for more laboratory experiments. Biological Reviews 84: 91-111. DOI: 10.1111/j.1469404 185X.2008.00064.X.

405

406 Melero Y, Palazón S, Bonesi L, Gosalbez J. 2008. Feeding habits of three sympatric mammals in 407 NE Spain: the American mink, the spotted genet, and the Eurasian otter. Acta Theriologica 53: 408 263. DOI: 10.1007/BF03193123. 
410 Montanari S, Amato G. 2015. Discrimination factors of carbon and nitrogen stable isotopes

411 from diet to hair and scat in captive tigers (Panthera tigris) and snow leopards (Uncia uncia).

412 Rapid Communications in Mass Spectrometry 29: 1062-1068. DOI: 10.1002/rcm.7194.

413

414 Pearson SF, Levey DJ, Greenberg CH, Martínez Del Rio C. 2003. Effects of elemental

415 composition on the incorporation of dietary nitrogen and carbon isotopic signatures in an

416 omnivorous songbird. Oecologia 135: 516-523. DOI: 10.1007/s00442-003-1221-8.

417

418 Pecquerie L, Nisbet RM, Fablet R, Lorrain A, Kooijman SA. 2010. The impact of metabolism on

419 stable isotope dynamics: a theoretical framework. Philosophical Transactions of the Royal

420 Society B 365: 3455-3468. DOI: 10.1098/rstb.2010.0097.

421

422 Pompanon F, Deagle BE, Symondson WO, Brown DS, Jarman SN, Taberlet P. 2012. Who is

423 eating what: diet assessment using next generation sequencing. Molecular Ecology 21: 1931-

424 1950. DOI: 10.1111/j.1365-294X.2011.05403.x

425

426 Post DM. 2002. Using stable isotopes to estimate trophic position: models, methods, and

427 assumptions. Ecology 83: 703-718. DOI: 10.1890/0012-9658(2002)083[0703:USITET]2.0.CO;2

428

429 R Core Team. 2016. R: A Language and Environment for Statistical Computing. R Foundation

430 for Statistical Computing, Vienna, Austria.

431 
432 Reitsema LJ. 2012. Introducing fecal stable isotope analysis in primate weaning studies.

433 American Journal of Primatology 74: 926-939. DOI: 10.1002/ajp.22045.

434

435 Rodgers TW, Janečka JE (2012) Applications and techniques for non-invasive faecal genetics 436 research in felid conservation. European Journal of Wildlife Research 59:1. DOI:

$437 \quad 10.1007 / \mathrm{s} 10344-012-0675-6$

438

439 Royer A, Queffelec A, Charlier K, Puech E, Malaizé B, Lenoble A. 2015. Seasonal changes in 440 stable carbon and nitrogen isotope compositions of bat guano (Guadeloupe). Palaeogeography, 441 Palaeoclimatology, Palaeoecology 440: 524-532. DOI: 10.1016/j.palaeo.2015.09.033

442

443 Salvarina I, Yohannes E, Siemers BM, Koselj K. 2013. Advantages of using fecal samples for 444 stable isotope analysis in bats: evidence from a triple isotopic experiment. Rapid

445 Communications in Mass Spectrometry 27: 1945-1953. DOI: 10.1002/rcm.6649.

446

447 Sare DT, Millar JS \& Longstaffe FJ. 2005. Tracing dietary protein in red-backed voles

448 (Clethrionomys gapperi) using stable isotopes of nitrogen and carbon. Canadian Journal of 449 Zoology 83: 717-725. DOI: 10.1139/z05-064.

450

451 Shehzad W, McCarthy TM, Pompanon F, Purevjav L, Coissac E, Riaz T, Taberlet P. 2012. Prey

452 preference of snow leopard (Panthera uncia) in South Gobi, Mongolia. PLOS ONE 7: e32104.

453 DOI: 10.1371/journal.pone.0032104.

454 
455 Sponheimer M, Robinson T, Ayliffe L, Passey B, Roeder B, Shipley L, Lopez E, Cerling T, 456 Dearing D, Ehleringer J. 2003a. An experimental study of carbon-isotope fractionation between 457 diet, hair, and feces of mammalian herbivores. Canadian Journal of Zoology 81: 871-876. DOI: $458 \quad 10.1139 / z 03-066$

459

460 Sponheimer M, Robinson TF, Roeder BL, Passey BH, Ayliffe LK, Cerling TE, Dearing MD, 461 Ehleringer JR. 2003b. An experimental study of nitrogen flux in llamas: is ${ }^{14} \mathrm{~N}$ preferentially 462 excreted? Journal of Archaeological Science 30: 1649-1655. DOI:10.1016/S0305463 4403(03)00066-9

464

465 Steele KW, Daniel RM. 1978. Fractionation of nitrogen isotopes by animals: a further 466 complication to the use of variations in the natural abundance of ${ }^{15} \mathrm{~N}$ for tracer studies. The 467 Journal of Agricultural Science 90: 7-9. DOI: 10.1017/S002185960004853X

468

469 Sutoh M, Koyama T, Yoneyama T. 1987. Variations of natural ${ }^{15} \mathrm{~N}$ abundances in the tissues and 470 digesta of domestic animals. Radioisotopes 36: 74-77. PMID:3575790.

471

472 Sutoh M, Obara Y, Yoneyama T. 1993. The effects of feeding regimen and dietary sucrose 473 supplementation on natural abundance of $15 \mathrm{~N}$ in some components of ruminal fluid and plasma 474 of sheep. Journal of Animal Science 71: 226-231. DOI: 10.2527/1993.711226x.

475 
476 Terry RC. 2010. The dead do not lie: using skeletal remains for rapid assessment of historical

477 small-mammal community baselines. Proceedings of the Royal Society of London B: Biological

478 Sciences 277: 1193-1201. DOI: 10.1098/rspb.2009.1984.

479

480 Wickham H. 2009. ggplot2: Elegant Graphics for Data Analysis. Springer, New York. 481

482 


\section{Table $\mathbf{1}$ (on next page)}

Fecal trophic discrimination factors of carbon $\left(\Delta^{13} \mathrm{C}\right)$ from this study and from the literature.

Average ${ }^{13} \mathrm{C}$ of diet used to calculate each TDF is included from the original listed publication. All isotope values are presented \pm 1 standard deviation if it was available in the original publication. Asterisks $(*)$ indicate when one species from the same experiment was divided into different diet treatments. The column " $n$ " represents the number of fecal samples used to calculate the TDF in each experiment. The $\Delta^{13} \mathrm{C}$ values in bold are statistically significantly different from zero in their original experiments. 


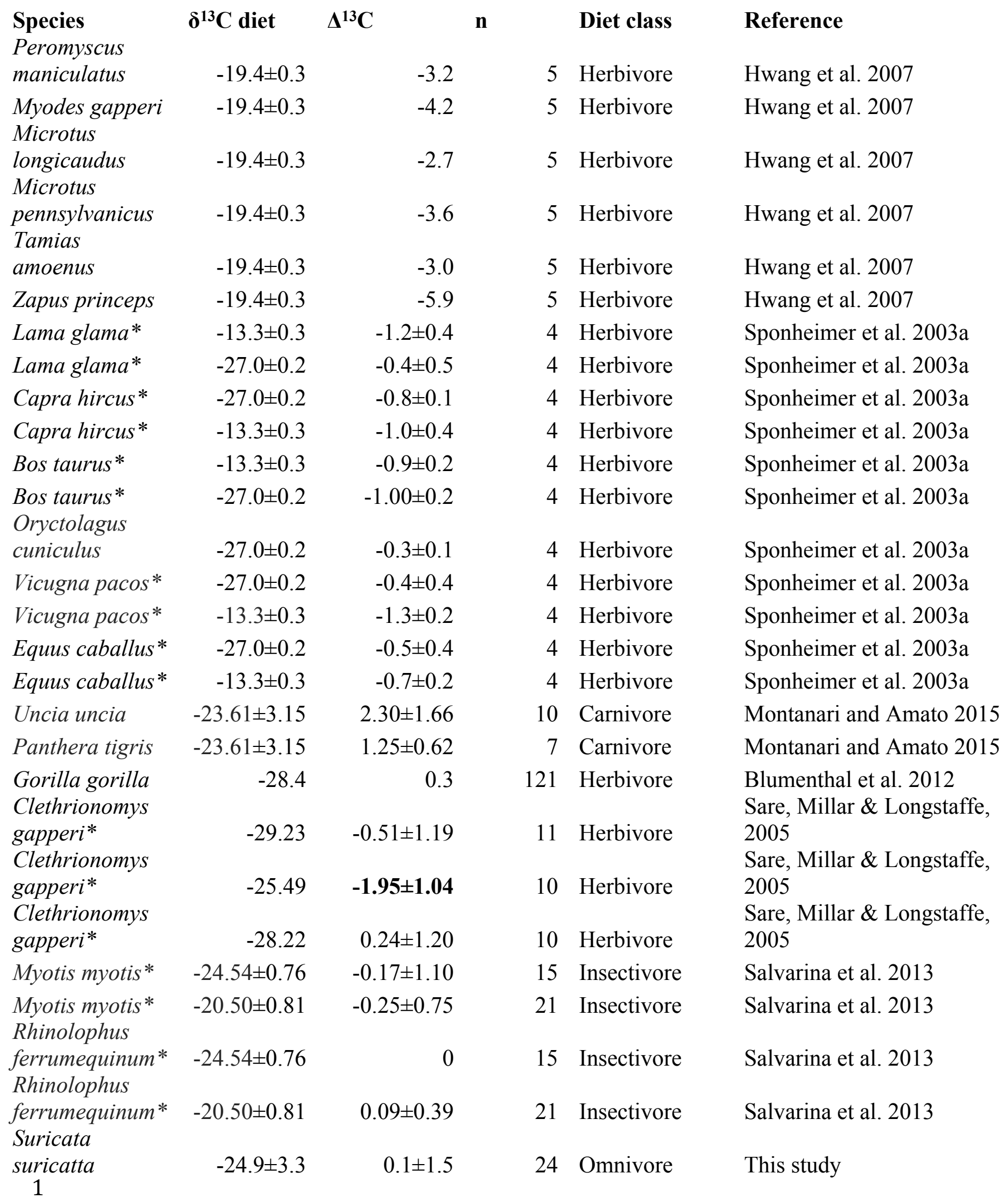




\section{Table 2 (on next page)}

Fecal trophic discrimination factors of nitrogen $\left(\Delta^{15} \mathrm{~N}\right)$ from this study and from the literature.

Average $\delta^{15} \mathrm{~N}$ of diet used to calculate each TDF is included from the original listed publication. All isotope values are presented \pm 1 standard deviation if it was available in the original publication. Asterisks $(*)$ indicate when one species from the same experiment was divided into different diet treatments. The column " $n$ " represents the number of fecal samples used to calculate the TDF in each experiment. The $\Delta^{15} \mathrm{~N}$ values in bold are statistically significantly different from zero in their original experiments. 


\begin{tabular}{|c|c|c|c|c|c|}
\hline $\begin{array}{l}\text { Species } \\
\text { Peromyscus }\end{array}$ & $\delta^{15} \mathbf{N}$ diet & $\Delta^{15} \mathbf{N}$ & $\mathbf{n}$ & Diet class & References \\
\hline maniculatus & $3.6 \pm 0.02$ & 2.1 & 5 & Herbivore & Hwang et al. 2007 \\
\hline $\begin{array}{l}\text { Myodes gapperi } \\
\text { Microtus }\end{array}$ & $3.6 \pm 0.02$ & 2.2 & 5 & Herbivore & Hwang et al. 2007 \\
\hline $\begin{array}{l}\text { longicaudus } \\
\text { Microtus }\end{array}$ & $3.6 \pm 0.02$ & 2.2 & 5 & Herbivore & Hwang et al. 2007 \\
\hline pennsylvanicus & $3.6 \pm 0.02$ & 2.5 & 5 & Herbivore & Hwang et al. 2007 \\
\hline Tamias amoenus & $3.6 \pm 0.02$ & 1.4 & 5 & Herbivore & Hwang et al. 2007 \\
\hline Zapus princeps & $3.6 \pm 0.02$ & 2.2 & 5 & Herbivore & Hwang et al. 2007 \\
\hline Lama glama* & 0.4 & $2.9 \pm 0.3$ & 4 & Herbivore & Sponheimer et al. $2003 \mathrm{~b}$ \\
\hline Lama glama* & 5.8 & $3.0 \pm 0.4$ & 4 & Herbivore & Sponheimer et al. $2003 \mathrm{~b}$ \\
\hline Bos taurus* & 0.7 & 2.0 & 4 & Herbivore & Steele and Daniel 1978 \\
\hline Bos taurus* & 0.6 & 1.7 & 4 & Herbivore & Steele and Daniel 1978 \\
\hline Equus caballus* & 0.4 & 2.6 & Unknown & Herbivore & Sponheimer et al. $2003 \mathrm{~b}$ \\
\hline Equus caballus* & 5.8 & 3.3 & Unknown & Herbivore & Sponheimer et al. $2003 \mathrm{~b}$ \\
\hline Ovis aries & 0.8 & 3.0 & Unknown & Herbivore & Sutoh et al. 1993 \\
\hline Capra hircus & 1.5 & 3.6 & 3 & Herbivore & $\begin{array}{l}\text { Sutoh et al. } 1987 \\
\text { Montanari and Amato }\end{array}$ \\
\hline Uncia uncia & $8.95 \pm 0.73$ & $2.49 \pm 1.30$ & 10 & Carnivore & $\begin{array}{l}2015 \\
\text { Montanari and Amato }\end{array}$ \\
\hline Panthera tigris & $8.95 \pm 0.73$ & $1.57 \pm 2.04$ & 7 & Carnivore & 2015 \\
\hline Sus scrofa & $4.6 \pm 0.3$ & 1.2 & 3 & Omnivore & Sutoh et al. 1987 \\
\hline $\begin{array}{l}\text { Gorilla gorilla } \\
\text { Clethrionomys }\end{array}$ & 3.2 & 0.6 & 121 & Herbivore & Blumenthal et al. 2012 \\
\hline $\begin{array}{l}\text { gapperi* } \\
\text { Clethrionomys }\end{array}$ & -0.42 & $1.76 \pm 1.26$ & 11 & Herbivore & Sare et al. 2005 \\
\hline $\begin{array}{l}\text { gapperi* } \\
\text { Clethrionomys }\end{array}$ & 1.45 & $1.17 \pm 1.68$ & 10 & Herbivore & Sare et al. 2005 \\
\hline gapperi* & 4.00 & $1.27 \pm 2.06$ & 10 & Herbivore & Sare et al. 2005 \\
\hline Myotis myotis* & $5.31 \pm 0.63$ & $1.81 \pm 1.28$ & 15 & Insectivore & Salvarina et al. 2013 \\
\hline $\begin{array}{l}\text { Myotis myotis* } \\
\text { Rhinolophus }\end{array}$ & $12.88 \pm 1.16$ & $2.34 \pm 2.17$ & 21 & Insectivore & Salvarina et al. 2013 \\
\hline $\begin{array}{l}\text { ferrumequinum* } \\
\text { Rhinolophus }\end{array}$ & $5.31 \pm 0.63$ & $0.53 \pm 0.54$ & 14 & Insectivore & Salvarina et al. 2013 \\
\hline ferrumequinum* & $12.88 \pm 1.16$ & $0.97 \pm 0.45$ & 21 & Insectivore & Salvarina et al. 2013 \\
\hline Suricata suricatta & $4.6 \pm 1.8$ & $1.5 \pm 1.1$ & 24 & Omnivore & This study \\
\hline
\end{tabular}




\section{Table 3(on next page)}

Stable isotope results from meerkat feces and diet samples $\left(\delta^{13} \mathrm{C}\right.$ and $\left.\delta^{15} \mathrm{~N}\right)$.

Means are shown \pm 1 standard deviation. Stable isotopes are presented in delta notation ( $\delta$ ) and discrimination factors are noted by $\Delta$. All isotope values are presented in per mil (\%o). Trophic discrimination factor in bold is statistically significant from zero. 


\begin{tabular}{|c|c|c|c|c|c|c|c|c|c|c|}
\hline & $\mathbf{n}$ & $\delta^{13} \mathrm{C}(\%)$ & $\delta^{13} \mathrm{C}$ range & $\delta^{15} \mathbf{N}(\%)$ & $\delta^{15} \mathbf{N}$ range & $\mathbf{C} / \mathbf{N}$ & $\mathrm{C} \%$ & N\% & $\Delta^{13} \mathrm{C}$ & $\Delta^{15} \mathbf{N}$ \\
\hline $\begin{array}{l}\text { Meerkat } \\
\text { scat }\end{array}$ & 24 & $-24.8 \pm 1.5$ & $-28.1,-20.7$ & $6.1 \pm 1.1$ & $4.4,8.9$ & $6.9 \pm 1.6$ & $20.9 \pm 11.1$ & $3.2 \pm 1.8$ & $0.1 \pm 1.5$ & $1.5 \pm 1.1$ \\
\hline Chick & 2 & $-26.1 \pm 1.2$ & $-27.0,-25.3$ & $4.5 \pm 0.03$ & 4.5 & $3.7 \pm 0.3$ & $47.8 \pm 0.3$ & $12.9 \pm 1.0$ & & \\
\hline Mouse & 2 & $-23.4 \pm 1.7$ & $-24.6,-22.2$ & $5.2 \pm 0.6$ & $4.7,5.6$ & $6.1 \pm 1.5$ & $51.4 \pm 4.7$ & $8.7 \pm 1.3$ & & \\
\hline Horse meat & 4 & $-27.1 \pm 1.3$ & $-28.2,-25.3$ & $7.0 \pm 1.3$ & $6.1,9.0$ & $3.5 \pm 0.04$ & $46.0 \pm 1.9$ & $13.3 \pm 0.4$ & & \\
\hline $\begin{array}{l}\text { Fruit mix } \\
\text { Dog }\end{array}$ & 4 & $-27.7 \pm 1.5$ & $-29.8,-26.8$ & $3.5 \pm 1.0$ & $2.8,4.9$ & $88.6 \pm 21.8$ & $38.5 \pm 1.0$ & $0.5 \pm 0.1$ & & \\
\hline biscuits & 4 & $-20.2 \pm 0.5$ & $-20.7,-19.5$ & $2.9 \pm 0.5$ & $2.3,3.4$ & $11.4 \pm 1.8$ & $42.9 \pm 0.7$ & $3.8 \pm 0.6$ & & \\
\hline $\begin{array}{r}\text { Total diet } \\
1\end{array}$ & 16 & $-24.9 \pm 3.3$ & $-29.8,-19.5$ & $4.6 \pm 1.8$ & $2.3,9.0$ & $27.1 \pm 38.1$ & $44.2 \pm 4.6$ & $7.1 \pm 5.5$ & & \\
\hline
\end{tabular}




\section{Table 4 (on next page)}

Results from t-tests ( $p$-value, $t, d f$ ) comparing $\delta^{13} \mathrm{C}$ and $\delta^{15} \mathrm{~N}$ means of stable isotope values from lipid and non-lipid-extracted meerkat feces and diet samples.

The t-test used (Welch or equal) was decided by a preliminary F-test to test for equal variances. 
1

$\begin{array}{rrrrrr}\text { Variable 1 } & \text { Variable 2 } & \text { Test } & \text { p-value } & \mathbf{t} & \text { df } \\ \delta^{13} \mathrm{C} \mathrm{Scat} \mathrm{LE} & \delta^{13} \mathrm{C} \mathrm{Scat} & \text { t-test equal } & 0.12 & 1.59 & 31 \\ \delta^{15} \mathrm{~N} \mathrm{Scat} \mathrm{LE} & \delta^{15} \mathrm{~N} \mathrm{Scat} & \text { t-test equal } & 0.09 & -1.74 & 31 \\ \delta^{13} \mathrm{C} \text { Diet LE } & \delta^{13} \mathrm{C} \mathrm{Diet} & \text { t-test equal } & 0.46 & 0.75 & 14 \\ \delta^{15} \mathrm{~N} \mathrm{Diet} \mathrm{LE} & \delta^{15} \mathrm{~N} \mathrm{Diet} & \text { t-test equal } & 0.79 & 0.27 & 14 \\ \delta^{13} \mathrm{C} \mathrm{Diet} & \delta^{13} \mathrm{C} \mathrm{Scat} & \text { Welch t-test } & 0.89 & -0.14 & 19.05 \\ \delta^{15} \mathrm{~N} \text { Diet } & \delta^{15} \mathrm{~N} \mathrm{Scat} & \text { Welch t-test } & 0.01 & -2.97 & 22.61\end{array}$


Figure 1

Variability in $\delta^{13} \mathrm{C}(\mathrm{a})$ and $\delta^{15} \mathrm{~N}(\mathrm{~b})$ values of meerkat feces over the month of sampling.

Points on the line represented a measured fecal sample. All isotope values are presented in per mil (\%o).
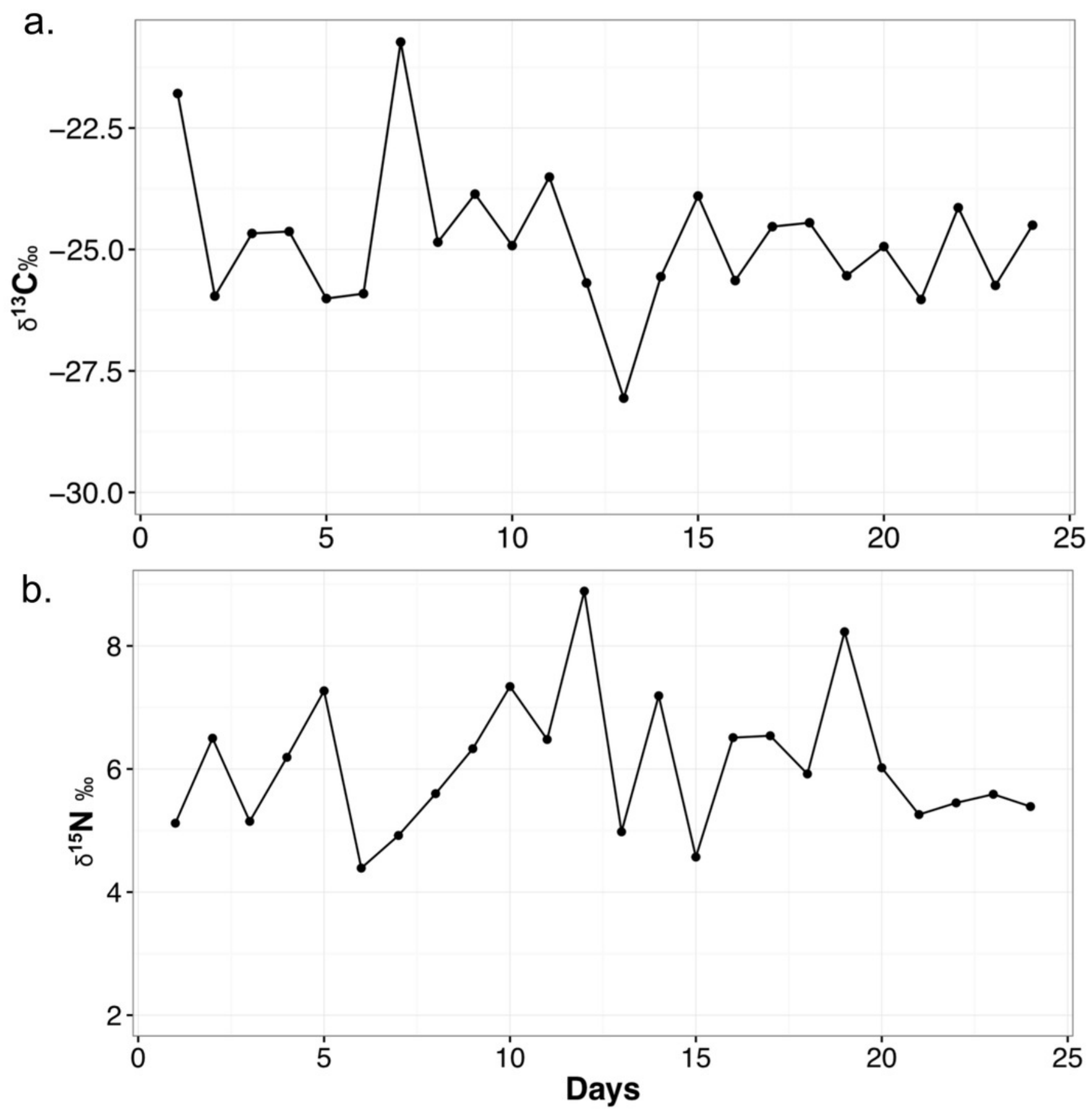